\title{
Taxation of Corporate Incomes with International Connections in Nigeria: Legal Issues Arising
}

\author{
Kwaghkehe Ierkwagh $\mathrm{PhD}^{1 *} \quad$ Ngunengen Ierkwagh, Esq. ${ }^{2}$ \\ 1.Department of Commercial Law, Faculty of Law, \\ Benue State University, P.M.B. 102119, Makurdi, Benue State, Nigeria \\ 2.Federal Ministry of Justice Headquarters, Abuja, Nigeria
}

\begin{abstract}
Corporate tax is of immense importance to national economies globally. It serves as an important source of government revenue and an indispensable armory for managing and directing national economies towards desired goals. Globalisation and advancements in technology have heralded an increased volume of trade and investment across national boundaries. Multinationals dominate this increased volume of international transactions in Africa while national corporations who are junior partners in the emerging global economy also do business abroad. Corporate income is therefore a fertile tax base for tax systems across the globe. The Nigerian tax system consequently subjects to tax global profits of a Nigerian company and profits or incomes of foreign companies that are derived from a source within Nigeria. This regime presents some practical legal problems for the tax system. Through the doctrinal research method, this paper has identified and discussed these emerging legal issues ranging from the problems of ascertainment of deductible expenses incurred abroad, international double taxation, transfer pricing abuse, and the non-enforceability of foreign tax laws and judgments abroad which tend to impact negatively on revenue generation. As a way forward, the paper finally suggests a selective signing of bilateral treaties in respect of double taxation agreements, and a multinational approach to serve as a check against the tendency of multinationals to default payment of taxes in their host countries.
\end{abstract}

Keywords: Taxation, Corporate, Incomes, International, Connections, Legal.

DOI: $10.7176 / \mathrm{JLPG} / 98-22$

Publication date:June 30th 2020

\section{Introduction}

A Corporation has been defined as a legal entity created under a state or other statute that allows incorporation by persons who become the shareholders of the corporation. ${ }^{1}$ Corporate income tax on the other hand, is tax chargeable on incomes of incorporated bodies, but excludes associations, partnerships, trusts and sole proprietorships. For tax purposes, corporations have been categorised as separate taxpayers from their shareholders, meaning that the corporate entity is subject to taxation on Corporate level event. ${ }^{2}$

In Nigeria, corporate income tax is charged on the incomes of Companies under the Companies Income Tax Act (CITA) ${ }^{3}$ and Petroleum Profits Tax Act (PPTA). ${ }^{4}$ Other business ventures like the sole proprietorship and the partnership are chargeable to tax under the Personal Income Tax Act (PITA). ${ }^{5}$

Corporate Income Tax is indispensable in economies of nations for several reasons. First, it is a major source of government revenue. For instance, in the United States of America, corporate tax collections exceeded $\$ 188$ billion by 1998 , representing approximately 11 percent of U.S. federal government revenues, or 2.2 percent of U.S. Gross Domestic Product (GDP). ${ }^{6}$ Secondly, corporate taxation is a very potent fiscal weapon in the hands of the government which can be effectively used to direct and manage the economy towards desired goals of the government. Towards this end, an increase in corporate tax rate is bound to have a trickle down effect on the economy in form of increase in prices of products which will consequently reflect negatively on consumption. Consequently, Hines submits that:

Corporate taxation increases the cost of producing output, thereby raising output prices, depressing demand, shifting output from the corporate sector of the economy to the non corporate sector. This relocation affects factor demands to the extent that factor input ratios differ between the corporate and non corporate sectors of the economy. ${ }^{7}$

This submission by Hines finds merit in the fact that in the short run, companies pay tax. However, in the long run, corporate taxes are shifted to the three components of a corporation. Companies shift taxes to the consumers through increased prices of products, to the workers through reduced wages, and to the shareholders through reduction in dividends. The overall picture is that corporate taxes have impacts on the economy that cannot be neglected.

Again corporate tax will prevent companies from simply being avenue or receptacles for concealing taxable incomes. Towards achieving this aim, Section 30(1) (b) of the CITA allows the tax authority to subject to tax foreign companies whose profits cannot be ascertain to tax base on its turnover.

Globalisation of trade and advancements in technology have broken down barriers that had hither impeded on trade or business across national boundaries. Consequently, both local and foreign companies carry out business 
activities that cut across national boundaries. The activities of these corporations with business connections in more than one country pose a lot of problems for the national tax systems. For instance, there are about 63,000 transnational corporations with more than 800,000 subsidiaries and affiliates. ${ }^{8}$ The problem posed to national tax authorities in this regard, is the ability to dictate whether or not the transactions taking place between the companies and their subsidiaries are fictitious or simply transfer pricing abuses. Closely related to the above is the issue of deductible expenses for tax purposes as it plays a crucial role in determining the chargeable incomes of corporate businesses with international links. These issues are capable of frustrating national tax systems, Nigeria inclusive. For they pose a lot of administrative problems to the Nigerian tax system, thereby negatively impacting on tax revenue of the country on business with international links.

This paper begins with the principles of liability to Nigerian tax by corporations. It then examines the forms and nature of businesses with international links, that are liable to Nigerian tax. Attention is then devoted to issues that frustrate the Nigerian tax system in the course of taxation of business with international links. Finally, attempts are made to draw attention to these issues under the backdrop of the Nigerian tax laws and international taxation while suggestions are made for overcoming the impediments towards effective taxation of corporate incomes with international connections.

In discussing the paper, basic assumptions are made. Firstly, the paper assumes that the reader is conversant with elementary principles of taxation. Secondly, that the reader can effectively appreciate terms like 'international' and 'incomes' which form crucial building blocks for the topic under discourse.

\section{Basis of Corporate Liability to Nigerian Tax}

Section 9 of the Companies Income Tax Act $^{9}$ which charges company profits to tax provides that:

1) Subject to the provisions of this Act, the tax shall, for each year of assessment, be payable at the rate specified in subsection (1) of section 40 of this Act upon the profits of any company accruing in, derived from, brought into, or received in, Nigeria in respect of -

a) any trade or business for whatever period of time such trade or business may have been carried on;

b) rent or any premium arising from a right granted to any other persons for the use or occupation of any property and where any payment on account of such a rent as is mentioned in this paragraph is made before the expiration of the period to which it relates and is induced for the purposes of this paragraph in the profits of a company, then, so much of the payment as relates to any period beginning with the date on which the payment is made shall be treated for these purposes as accruing to the company proportionately from the day to day over the last mentioned period or over the five years beginning with that date, whichever is the shorter;

c) dividends, interests, royalties, discounts, charges or annuities;

d) any source of annual profits not failing within the proceeding categories;

e) any amount deemed to be income or profit under a provision of this Act or, with respect to any benefit arising from a person or provident fund, of the Personal Income Tax Act;

f) fees, dues, and allowances (wherever paid) for services rendered;

g) any amount of profits or gains arising from acquisition and disposal of short-term money instruments like Federal Government securities, treasury bills, treasury or savings certificates, debenture certificates or treasury bills, treasury or savings certificates, debenture certificates or treasury bonds.

2) For the purpose of this Section, interest shall be deemed to be derived from Nigeria if -

a) there is a liability to payment of the interest by a Nigerian company or a company in Nigeria regardless of which way the interest may have accrued.

To be liable to tax in Nigeria, therefore, an income or profit must have accrued in, derived from, brought into or received in Nigeria. To give effect to this, the Companies Income Tax Act has divided companies into two broad categories for tax purposes ${ }^{10}$, viz; Nigerian companies and foreign companies. Section 105(1) of the Companies Income Tax Act goes further to define a Nigerian company to mean any company incorporated under the Companies and Allied Matters Act or any enactment replaced by that Act while a foreign company is defined to mean any company or corporation (other than a corporation sole) established by or under any law in force in any territory or country outside Nigeria.

This distinction is very important for tax purposes. The global profits of a Nigerian company are taxable in Nigeria whether or not all or any part of the profits have been remitted into Nigeria ${ }^{11}$, while profits of a foreign company are taxable in Nigeria only to the extent that they are derived from a source within Nigeria. According to Section 13 -

1) The profits of a Nigerian company shall be deemed to accrue in Nigeria wherever they have risen and whether or not they have been brought into or received in Nigeria.

2) The profits of a company other than a Nigerian company from any trade or business shall be deemed 
to be derived from Nigeria -

a) if that company has a fixed base of business in Nigeria to the extent that the profit is attributable to a fixed base;

b) if it does not have such a fixed base of business in Nigeria but habitually operates a trade or businesses through a person in Nigeria authorised to conduct on its behalf or on behalf of some other companies controlled by it or which have a controlling interest in it; or habitually maintains a stock of goods or merchandise in Nigeria from which deliveries are regularly made by a person on behalf of the company, to the extent that the profit is attributable to the business or trade or activities carried on through that person;

c) if that trade or business or activities involves a single contract for surveys, deliveries, installations or construction, the profit from that contract; and

d) where the trade or business or activities is between the company and another person controlled by it or which has a controlling interest in it and conditions are made or imposed between the company and such person in their commercial or financial relations which in the opinion of the Board is deemed to be artificial or fictitious, so much of the profit adjusted by the Board to reflect arm's length transaction.

The combined effect of Sections 9 and 13 of CITA is, that the global profits of Nigerian companies are taxable in Nigeria whether or not they are brought into, received in or imported into Nigeria, while for foreign companies, it is only the profits that are derived from a source within Nigeria that are liable to Nigerian tax. For our present purposes therefore, the taxation of corporate incomes or profits with international connections in Nigeria can be appreciated from this perspective. That is, global incomes or profits of Nigerian companies and profits of foreign companies derived from a source within Nigerian collectively belong to this class of corporate incomes with international connections.

There have been controversies as to whether or not residence is an important factor in determining corporate tax liability in Nigeria. The residence of a company and the extent to which residence is a material factor in determining the tax liability of a company presents a problem for international taxation. Abdulrazaq ${ }^{12}$ argues, that $^{2}$ the residence of a company is a very material factor in determining its tax liability in Nigeria and is of great importance as a means of avoiding double taxation (both internal and external). He maintains the position that though statute law has not laid down any general rule for determining where a company is resident, resort has been had to English courts by the Nigerian courts in determining the residence of a company, and that English courts are unanimous that the test in determining the residence of a company for tax purposes is where its real business is carried on, and the business is carried on where the central management and control actually resides.

However, Kanyip ${ }^{13}$ disagrees and takes the opposite view that residence is not the primary test of liability to company tax in Nigeria but that the test is whether the income accrued in, was derived from, brought into or received in Nigeria, and that even this test is subject to Section 11(1) of the CITA, 1990, which deems all incomes as accruing in Nigeria wherever derived from. The consequence, according to Kanyip ${ }^{14}$, Abdulrazaq was carried away by some factors in reaching his conclusion. First, that the later assumed wrongly that the charging provision under Section 8(1) CITA, 1990 is the same as that of the United Kingdom. Under the U.K. Finance Act, 1988, a company will fall within the charge to corporation tax on its worldwide income and gains if it is resident in the U.K., and a company resident in the U.K. if with effect from $15^{\text {th }}$ March, 1988, it is incorporated in the U.K., or before that date its central management and control was located in the U.K. pursuant to Section 66 Schedule 7. Kanyip $^{15}$ therefore concludes that in view of this provision, the primary test of liability to corporation tax in the U.K. is residence and that there is no such test in the Nigerian Act. Secondly, that the opinion of Abdulrazaq may be based on the position under the CITA, 1990 where Section 2 defined a Nigerian company as one in which the control and management of which is carried out in Nigeria, but that this test has been undertaken by Section 84 of CITA, 1990. Thirdly, that the fact that residence determines tax liability under the Personal Income Tax provisions may have influenced Abdulrazaq, and concludes that Personal Income Tax and Companies Income Tax are different taxes chargeable under separate enactments.

This debate however ends in a draw. Abdulrazaq is not mindful of the fact that for foreign companies, residence is not of any importance in respect of income tax liability. What is important is a fixed based of a foreign company. Once a foreign company has a fixed base in Nigeria, a reasonable percentage of the part of the turnover attributable to the fixed base is liable to corporate tax. ${ }^{16}$ Kanyip on the other hand, lost sight of the position that a company incorporated in Nigeria is a Nigerian company and Section 35(b) of Companies Income Tax Act (CAMA), 1990 is not leeway for companies to locate their head office abroad. Both the registered office of the company and the head office must be situate in Nigeria. And once a Nigeria company, its global profits or gains are chargeable to tax in Nigeria. In conclusion, for a Nigeria company, its global profits are deemed to accrue in and subjected to company income tax in Nigeria whether or not any part of such gains or profits have been remitted to or received in Nigeria. ${ }^{17}$ But profits of foreign companies are taxable in Nigeria only to the extent that they are derived from a source within Nigeria. ${ }^{18}$ So, both residence and source are important considerations in determining 
corporate liability to income tax in Nigeria.

\section{Legal Issues}

In taxing corporate incomes or profits with international connections in Nigeria, some legal issues emerge which are central to the entire tax system, and if not carefully handled are bound, to impact negatively on revenue generation.

\subsection{Deductible Expenses for Tax Purposes}

For the purpose of ascertaining the taxable income or profit of a company, Section 24 of the Companies Income Tax Act allows deductions which are incurred wholly, exclusively, necessarily and reasonably for the purpose of such business or trade. This is meant to limit deductible expenses to the actual amount expanded directly in the production of an income. Thus, incidental expenses are not allowed. ${ }^{19}$ Kaldor has rightly observed that:

If expenses are allowed which are not a necessary or an inevitable concomitant or producing the receipts against which they are set off, the Government, in effect, is subsidising such expenditure through the instrument of taxation. In the case of avoidance items, no such subsidy is involved precisely because the trading receipts are directly dependent on them. ${ }^{20}$

The Companies Income Tax Act ${ }^{21}$ has therefore listed deductible items to include any sum payable by way of interest on money borrowed, rent for the period of business, premium, salary, wages, expenses for repair of premises, plant, machinery or fixtures employed in acquiring the profits, and bad and doubtful debts. In respect of businesses in particular, the $\mathrm{Act}^{22}$ provides specifically as follows:

i) In the case of profits from a trade or business, any expenses or part therefore -

i) the liability for which was incurred during that period wholly, exclusively, necessarily and reasonably for the purposes of such trade or business and which is not specifically referable to any other period or periods; or

ii) the liability for which was incurred during any previous period wholly, exclusively, necessarily and reasonably for the purpose of such trade or business and which is specifically referable to the period of which the profits are being ascertained; and

iii) the expenses proved to the satisfaction of the Board to have been incurred by the company or research and development for the period including the amount of levy paid by it to the National Science and Technology Fund which is not deductible under any other provision of this Section;

j) Such other deductions as may be prescribed by the Minister by any rule.

On the part of the Petroleum Profits Tax $\mathrm{Act}^{23}$, Section 10 thereof provides an elaborate list of items that qualify as deductible expenses for tax purposes which are similar to those under Companies Income Tax Act. ${ }^{24}$ These include rents, royalties incurred during the period of operations, interest on loans, cost of repair of premises, plants, machinery or fixtures incurred in the course of petroleum operations during the period, bad or doubtful debts, expenditure including tangible drilling costs, contributions to a pension, provident or other approved society, scheme or fund, and all sums the liability of which was incurred by the company during the period of petroleum operations. These expenses must have been incurred wholly, exclusively, necessarily and reasonably for the purpose of petroleum operations.

The problem however has being the interpretation of these provisions in respect of corporate deductible expenses to determine with certainty what items qualify as deductible expenses for tax purposes or to arrive at taxable profits. The courts and Tax Appeal Tribunal, have often been called upon for assistance. In a plethora of decided authorities, the Nigerian courts and the Tax Appeal Tribunal, have grappled with this conundrum.

In Shell Petroleum Development Company of Nigeria Limited V. Federal Board for Inland Revenue ${ }^{25}$, the issue arose as to whether or not Exchange losses incurred by the company pursuant to an agreement in the course of petroleum operations were, wholly, necessarily and exclusively incurred as used by the Petroleum Profits Tax Act and therefore deductible expenses. The Supreme Court held, that exchange losses incurred by the company were deductible expenses. In South Atlantic Petroleum Limited \& 2 Ors V. Federal Inland Revenue Service ${ }^{26}$, the Appellants filed their Petroleum Profits Tax returns on OML-130 PSA Contract Area for 2009, 2010, and 2011 tax years respectively and paid their Education Tax. The allowable expenses claimed in the returns included, "sole costs" of $\$ 151,345,130.54$; $\$ 148,173,01.91$; and $\$ 113,449,449,456.60$ for the respective years. The Respondent disallowed the sums which expenditure, the Appellants claimed were wholly, exclusively, and necessarily incurred by them for the purpose of petroleum operations. And as a result of disallowing the above expenses, the Respondent raised additional tertiary education tax assessments for 2009, 2010, and 2011 assessment years respectively. Allowing the deductions as claimed by the company, the Tax Appeal Tribunal, Lagos Zone held as follows:

The Respondent foreclosed the import of Section 10 of the PPTA in its decision to disallow the sole costs expanded on OML-130 PSA by the Appellants. In computing Petroleum Profits Tax, deductible expenses are determined on the basis of Section 10 of PPTA i.e. WEN tests, and not otherwise. The Respondent's 
decision to ignore Section 10 of PPTA on the altar of it being 'inconsistent' with Sections 8 and 15 of DOIBA is lame.

Similarly, in Shell Petroleum Development Company of Nigeria Limited V. Federal Inland Revenue Service ${ }^{27}$, the issue before the Tax Appeal Tribunal, was whether or not the sum of US \$94,707,348 and US \$2,228,408 being interest paid by the Appellant on intercompany loan are deductible within the meaning of Section 10(1) (g) of the Petroleum Profit Tax Act having been obtained at arm's length from a sister company. Answering the issue in the affirmative, the Tax Appeal Tribunal held that:

Interest payments made on intercompany loan which obtained in accordance with arm's length principle are deductible based on the provision of Section 10(1) $(\mathrm{g})$ of the PPTA...

It may be observed, that all companies involved in the above cases have foreign connections and that all decisions went in their favour. This judicial indulgence represents an unwarranted regime of double subsidy to foreign investors particularly that there already exists a favourable legal tax regime.

A further problem created by the charging provision which allows for the deductibility of expenses incurred in the course of production is that, it does not limit deductible expenses to those incurred locally. Therefore, it is difficult for Nigerian tax authorities to monitor the global expenses of companies for tax purposes.

Even Section 27(1) of the Companies Income Tax $\mathrm{Act}^{28}$ does not help matters as it provides, that it is expenses incurred for and on behalf of any company outside Nigeria by another taxable company that are disallowable deductions. In Nigerian Breweries Plc V. Federal Inland Revenue Service ${ }^{29}$, the Tax Appeal Tribunal held, that Section 27(1) does not apply to all expenses incurred by the taxable company, but only those incurred for an entity are disallowable. The deductible expenses incurred by a company abroad therefore have the potential to open the gate for the tax avoidance and evasion industry to flourish.

\subsection{Transfer Pricing Abuse}

Transfer pricing is a process where goods and services are exchanged within a single multinational corporation. It becomes abuse where intra-company transactions are not at arm's length. According to an estimate prepared in the late $1990 \mathrm{~s}, 60$ percent of the trade transactions into or out of Africa are mispriced through abusive transfer pricing and re-invoicing, 11 percent, resulting in capital flight component of 7 percent of African trade, totaling U\$\$10 to 11 billion annually in 1999 prices. ${ }^{30}$ Globally, it has been estimated that there are 63,000 transnational corporations with more than 800,000 subsidiaries and affiliates. ${ }^{31}$

Transfer pricing abuse is the biggest single problem to the tax systems of both developed and developing countries. ${ }^{32}$ Singh $^{33}$ therefore summarised the implications of this manipulative transfer pricing to include the fact that the corporations make more profits and that of loss of revenue to countries. According to Singh ${ }^{34}$ this trend is very important for developing countries, because most developing countries rely on corporate taxation as part of the revenue generation gains.

Africa, being a developing economy has a bitter experience of the pandemic called "transfer pricing abuse" by multinationals. In Unilever Kenya Limited (formerly East African Industries Limited) $V$. The Commissioner of Income $\operatorname{Tax}^{35}$, the Kenyan High Court as per Alnashir Visram, J. stressed the destructive consequences of transfer pricing on the economy and the need for its regulation in the following words:

Transfer prices adopted by a multinational in respect of transactions between its various subsidiaries and affiliates, have a direct beaming on the proportional profit it derives in each country in which it operates. There is a wide agreement amongst revenue authorities and amongst participants in the industry that foreign owned businesses in their jurisdiction should not be permitted to pay proportionately less tax than domestic businesses by rigging their inter-group pricing structure to reduce the profits of their branches or subsidiaries.

The problem faced by national tax authorities, Nigeria inclusive, is how to monitor intra-company transactions and determined whether every transaction taking place within these corporations is real or fictitious or simply an act of 'transfer mispricing', as Kukpoor puts it. ${ }^{36}$

In order to curtail the incidence of transfer pricing abuses, the Organisation for Economic Cooperation and Development (OECD) International Guidelines have prescribed methods for the calculation of prices at arm's length for a proper and reasonable determination of prices of items in disposals within a corporation and its subsidiary. In respect of Kenya, the court in Unilever Kenya V. CIT ${ }^{37}$ approved the Comparable Uncontrolled Price method (the CUP method) in the absence of any guidelines by the Kenyan law for the determination of an arm's length price as being the most direct method. This method compares the price charged for goods or services transferred in a controlled transaction to the price charged for goods or services transferred in a comparable uncontrolled transaction (like a transaction between independent enterprises) in comparable circumstances. If any difference is noticed between the two prices, the transaction is not deemed to be at arm's length.

Nigeria, though not a member of the OECD has adopted the OECD guidelines in both the Companies Income Tax $\mathrm{Act}^{38}$ and Petroleum Profits Tax Act ${ }^{39}$ specifically, Section 22(1) (1) of the Companies Income Tax Act ${ }^{40}$ provides: 
1) Where the Board is of the opinion that any disposition is not in fact given effect to or that any transaction which reduces or would reduce the amount of any tax payable is artificial or fictitious, it may disregard any such disposition or direct that such adjustment shall be made as respects liability to tax as it considers appropriate of liability to tax affected, or reduction which would otherwise be affected, by the transaction and any company concerned shall be assessable accordingly.

Section 22(2) (b) explains further that:

Transactions between persons one of whom either has control over the other or, in the case of individuals, who are related to each other or between persons both of whom are controlled by some other persons, shall be deemed to be artificial or fictitious if in the opinion of the Board those transactions have not been made on terms which might fairly have been expected to have been made by persons engaged in the same or similar activities dealing with one another at arm's length.

Section 15(1) of the Petroleum Profits Tax Act is on all fours with the above provisions. Despite the OECD guidelines and the provisions of Nigerian tax laws, it is doubtful if an acceptable market transaction can be established to set an arm's length price globally. Global arm's length acceptable prices can only be imagined.

The OECD Guidelines for Multinational Enterprises have made remarkable strides in the area of tax compliance by multinationals in their host economies. Specifically Guideline X states that:

It is important that enterprises contribute by making timely payment of their tax liabilities. In particular, enterprises should comply with tax laws and regulations in all countries in which they operate and should exert every effort to act in accordance with both the letter and spirit of those laws and regulations. This would include such measures as providing to the relevant authorities the information necessary for the correct determination of taxes to be assessed in connection with their operations and conforming transfer pricing practices to the arms length principle. ${ }^{41}$

This is commendable since some multinationals are members of the OECD. The efficacy of the Guidelines is however doubtful. Firstly, the Guidelines have no binding force. Secondly, the implementation may be resisted by multinationals. However, they represent the right direction towards achieving global tax compliance by multinational enterprises in their host countries, mainly countries of the south.

\subsection{International Double Taxation}

In the context of international taxation, double taxation has been defined as, the imposition of similar taxes in two or more countries on the same taxpayer in respect of the same subject matter. ${ }^{42}$ The National Tax Policy on the other hand defines "Multiple Taxation" to include, the imposition of the same or similar taxes on the same income base, transaction or person by one or more levels of Government, in one or more jurisdictions. ${ }^{43}$ 'Double taxation' and 'multiple taxation' therefore imply a situation where the same income in the hands of the same taxpayer is taxed more than once by the same tax authority or different tax authorities. For our present purposes, double taxation simply implies the imposition of tax on the same income or tax base in two or more jurisdictions. That is, a taxpayer may be subject to tax on the same income in one country on account of his personal status like residence, nationality or domicile, and in another country on account of the source of his income which is situate within that territory. In some cases, double taxation treaties require that tax be paid in the country of residence and exempt in the country in which it arises. In others, the country where the gain arises deducts taxation at source (withholding tax) and the taxpayer receives a compensating tax credit in the country of residence to reflect the fact that tax has already been paid. To do this, the taxpayer must declare himself (in the foreign country) to be non-resident there.

International double taxation may serve as disincentive to foreign investment, international trade or even transfer of technology, a necessary ingredient for development. Developing nations therefore stand to benefit from the gains of globalisation if efforts are made to curb the menace of double taxation to the barest minimum.

The disincentive effects of international double taxation liability are usually mitigated by double taxation treaties or agreements between countries. These bilateral treaties serve as relief from double taxation as the liability of the taxpayer on the same tax base is limited to one of the contracting states. In Saipem Contracting Nigeria Ltd. \& 2 Ors V. Federal Inland Revenue Service \& $2 \mathrm{Ors}^{44}$, the Federal High Court, Lagos Division explained the object of Double Taxation Agreement as follows:

Double Taxation Agreement is not meant to give the tax which is due to one country to another but to ensure the same income is not taxed twice by two different countries. There is nothing to show that this transaction has suffered tax in another tax jurisdiction.

The second aspect of double taxation treaties is the exchange of tax information between the contracting states. Most existing double taxation treaties follow the Organisation for Economic Cooperation and Development (OECD) Double Taxation Convention. ${ }^{45}$ According to this treaty model, countries are allowed to tax the income from foreign investment of their multinational firms either according to the credit system or the exemption system. Under the credit system, countries may tax international investment income through which both domestic and foreign profits are subject to domestic taxation, but foreign profits paid abroad are credited against domestic taxes on foreign profits. The maximum credit is however, the domestic tax liability or foreign profits. That is, the 
domestic government does not fully refund foreign taxes if foreign tax rate is higher than the domestic rate. Under the exemption system, foreign profits are exempt from domestic taxation. As a result, capital income is effectively taxed according to the source principle.

Apart from these forms provided by the OECD Double Taxation Convention, double taxation treaty may also be secured through charging of tax at a reduced rate in one of the treaty countries.

In recognition of the potentialities of double taxation treaties or agreements as a source of stimulating foreign investment and international trade, Nigeria has entered into double taxation treaties with a number of countries. ${ }^{46}$ The model treaty adopted by Nigeria, is the credit system. An important feature of this model treaty adopted by Nigeria is the concept of 'Permanent Establishment'. Under the treaty, an individual is taxed on the basis of 'Permanent Establishment' ${ }^{47}$ Permanent Establishment is said to exist either on the basis of fixed base, agency or project site. ${ }^{48}$ In the Indian case of Director of Income Tax V. M/SE Funds IT Solution ${ }^{49}$, the High Court of New Delhi held, that the word 'permanent' in the expression of Permanent Establishment, is of significance and imperial importance, and refers to some degree of permanency and not a mere transitory nature of the business in the other state.

Under Permanent Establishment treaty, the profit of an enterprise of a contracting state is taxed only in the state where it is resident and not in other state, even if activities have a business connection in the second state. This ensures that the same income is not taxed twice in the hands of the same person merely because there is a business connection between incomes earned by one assessment from activities in the two states.

Despite the seeming benefits of double taxation treaties in terms of stimulation of foreign investment, it is doubtful whether Nigeria can also reap such benefits from double taxation treaties given the country's volatile environment characterised by the menace of banditry, insurgency and infrastructural deficiency making the country unsafe for even local investment and trade. Secondly, double taxation treaties only stand to impact positively on economies with significant volume of foreign investment and international trade. Nigeria is a monocultural economy exporting only oil and importing almost every other goods from the West.

The implication is that the incomes earned by Nigerian companies abroad which would have formed the subject of tax exemption under double taxation treaties are not significant. Conversely, foreign companies dominate the Nigerian economy both in trade, and supply of goods and services. Any double taxation treaty which would seek to exempt incomes of foreign companies from tax in Nigeria would serve no useful purpose but simply deny the Nigerian government of significant revenue.

\subsection{Non-Enforceability of Tax Laws Abroad}

Another legal problem created by the charging provisions of the Companies Income Tax Act is whether or not Nigerian tax laws are enforceable abroad. It has been firmly established by a chain of court decisions, that a foreign court will not take notice of revenue law of another country. ${ }^{50}$ In Boucher V. Lawson ${ }^{51}$, the House of Lords, upholding the decision of the Court of Appeal, rejected a claim for recovery of Capital Gain Tax levied by the Indian Government on a company trading in India but whose major assets had been transferred to England shortly before it was wound up. Viscount Simmonds lamented over this claim to the effect, that he was "greatly surprised to hear it suggested that the courts of this country would and should entertain a suit by a foreign state to recover a tax".

Worst still, judgment based on such foreign taxes cannot be enforced in the forum. ${ }^{52}$ These positions have far-reaching implications for the global economy. First, the implication is that a tax defaulting foreign company cannot be proceeded against in the home country, once such company has no assets in Nigeria. Secondly, even if the foreign company's profit sought to be taxed were derived from a source within Nigeria and judgment obtained against the company for default in Nigeria, such judgment cannot be enforced in the home country of the company.

According to Lord Keith ${ }^{53}$, the doctrine of non-enforceability and recognition of foreign tax laws can be justified on two grounds. First, he maintains that the enforcement of a tax claim is but an extension of sovereign authority by one state within the territory of another and secondly, that the enforcement of foreign revenue law of another country may commit the domestic state to a position which would seriously embarrasses its neighbours. ${ }^{54}$

Yakubu $^{55}$ however submits that the arguments of Lord Keith in this regard are misplaced. According to him, as for the first contention, when a foreign court seeks to enforce its revenue laws in another country, it does not in any way assert sovereignty as such. Agbede ${ }^{56}$ puts it more blunt that to talk of sovereignty in this context is to indulge in technical quibbles. As to the second contention by Lord Keith ${ }^{57}$ in relation to sovereignty, Yakubu ${ }^{58}$ does not see any merit in it and argues that it is rather a flat refusal to entertain such a suit that would even be more embarrassing than a refusal to implement the law on any other ground, since such a refusal is tantamount to affording sanctuary in another state of tax evaders.

Ijohor ${ }^{59}$ is of the view, that tax laws which are not unjust, not difficult to enforce, unimpressive or contrary to public policy, and can be enforced by the domestic courts should be enforced by foreign courts. He argues that the way out of the problem created by the doctrine of non-enforceability of foreign tax laws is through bilateral treaties aimed at facilitating the international enforcement of fiscal laws. Ijohor's arguments on the principles that 
should guild the enforceability of foreign tax laws, can be faulted on the ground that terms like "unjust", "oppressive" or "contrary to public policy" may not have universal application. For example, what is contrary to public policy in one country may not be in another. The bilateral approach he suggested appears more attractive in solving the problem of international enforcement of tax laws and judgments.

\section{Summary/Findings}

Corporate taxation is indispensable in economies globally. A review of the normative arguments for corporate tax in Nigeria shows, that it is important as a source of revenue generation and an instrument for regulating the economy.

In Nigeria, the relevant tax laws subject to tax the global profits or incomes of Nigerian companies, while only profits or incomes of foreign companies derived from a source within Nigeria are chargeable. However, this tax regime of corporate incomes with international connections presents a lot of practical and conceptual problems to the Nigerian tax system which have the capacity to frustrate the revenue generation machinery and therefore impact negatively on development and growth.

The charging provisions in respect of corporate taxation which subjects to tax global profits of a Nigerian company stands the risk of being frustrated due to the fact that Nigeria does not have the machinery to monitor the global businesses of these companies in order to ascertain deductible expenses incurred for tax purposes.

Another problem posed to the Nigerian tax system in the taxation of incomes with international connection, is transfer mispricing or abuse. The Nigerian economy is dominated by subsidiaries of multinational corporations. Through intra-company exchange of equipments not at arm's length, multinational corporations make more profits by reducing their taxable incomes. This is tax avoidance capable of having negative consequences on the revenues of the host state. The problem faced by the national tax systems is how to monitor these intra-company transactions and determine whether or not they are fictitious or not at arm's length.

International double taxation has also been shown to serve as a disincentive to international trade and investment in the country. The destructive effects of international double taxation have consequently been mitigated through bilateral treaties also called double taxation agreements between Nigeria and her trading partners. However, the volatile environment, infrastructural deficiency and unequal trade relationship may constitute major impediments to achieving the desired results in the country.

Despite the fact that globalisation has broken down national boundaries and opened all countries of the world to trade and foreign investment, tax laws have not been properly fashioned to fit into the global economy and check abuses by foreign capital. For instance, it has been firmly established, that a foreign court will not take notice of revenue law of another country. Again, judgments based on foreign taxes cannot be enforced in the forum. These positions have far-reaching implications for the global economy, and the Nigerian economy in particular. First, a tax defaulting company cannot be proceeded against in the home country. Second, even if the foreign company's profits sought to be taxed were derived from a source within Nigeria, and judgment obtained against the defaulting company in Nigeria, such judgment cannot be enforced in the home country of the company. The overall picture is that tax laws have no answer to a defaulting corporate taxpayer who is able to escape out of the country and maintains no assets in Nigeria.

In terms of the universality principle for the taxation of corporate incomes in Nigeria under the backdrop of residence and derivability of incomes, the problem posed to Nigerian tax authorities is that of identification of the worldwide incomes of Nigerian companies.

\section{Recommendations}

The impediments to the taxation of corporate incomes with international connections have been identified and extensively discussed in this paper. The task left for the paper therefore, is to offer solutions towards overcoming these impediments not only in Nigeria, but infact, the entire emerging global economy.

First, in solving the problem of international double taxation and information on global incomes of Nigeria companies and expenses incurred in the course of production, the signing of bilateral treaties may be useful. Nigeria must enter into double taxation agreements with other countries for the exchange of information on Nigerian companies that do business in the treaty countries. This has the capacity of solving the problem of identification of companies, their incomes and expenses incurred abroad for tax purposes. However, caution must be exercised in terms of exemption from tax of incomes earned by Nigerian companies abroad. This is in view of the fact that Nigeria does not stand to gain from such agreements if the volume of her exports to the treaty partner and corporate incomes of Nigerian companies in those countries are not significant.

Another way out of the global tax problems is a multinational approach. With globalisation, multinational companies have firmly taken roots in developing countries. Indeed, multinational companies dominate trade in goods and services, and the construction industry in developing countries, Nigeria inclusive. A strong legal regime that can provide effective checks against multinational companies tendency to default payment of taxes in their host nations and relocate to either their home countries or elsewhere with impunity as in the case of Boucher V. 
Lawson $^{60}$ is desirable. The way out of this dilemma of national tax authorities is a multinational convention that would ensure the recognition of foreign revenue laws, entertainment of suits by foreign states to recover tax and enforcement of foreign judgments on foreign taxes.

Closely related to the above is the fact that the United Nations can pass a resolution compelling home governments of tax defaulting companies who have found their way back home to extradite the directing minds of such companies back to their host countries to fulfill their tax obligations. Though citizens who are involved in tax evasion (which is a crime) can be extradited under the United Nations Convention Against Transnational Organised Crimes (PALERMO) Convention ${ }^{61}$, the said convention does not cover civil offences or judgments.

\section{Conclusion}

There is no gain saying that taxation knows no national boundaries as tax liabilities of corporations may arise in other jurisdictions other than the country of residence. However, practical issues may constitute legal impediments in taxation of corporate incomes across national boundaries. Consequently, this paper has undertaken a discourse of such legal issues which include problems of ascertainment of deductible expenses incurred abroad, international double taxation, transfer pricing abuse and non-enforceability of foreign tax laws and judgments abroad. These legal issues have the potentials to frustrate national tax systems.

At the local scene, it will be beneficial for Nigeria to pursue a regime of selective signing of double taxation agreements to solve the problem of international double taxation which is a crucial factor for investment decisions by foreign capital. There must be a targeted approach and coordinated effort at designing a double taxation agreement regime that will be beneficial to and meet the aspirations and objectives of the Nigerian tax system.

At the multilateral level, it is time for coordinated international efforts against attempts by multinational corporations to frustrate national tax systems. In this regard, the paper recommends the passing of a resolution by the United Nations compelling home governments of tax defaulting companies who have found their way back home to extradite the directing minds or financers of such companies back to their host countries to fulfill their tax obligations.

Though, not all embracing, it is hoped that if pursued, these proposals have the capacity to largely solve the problems of taxation of corporate incomes with international connections by developing countries, Nigeria inclusive.

\section{References}

1. L. Lederman, 'Understanding Corporate Taxation' <www.lapres.net> p. 1 accessed on $27^{\text {th }}$ March, 2020.

2. Ibid.

3. Cap. C21 LFN, 2004.

4. Cap. P13 LFN, 2004.

5. Cap. P8 LFN, 2004 (as amended by Act No. 20, 2011).

6. R. James Hines Jr., 'Corporate Taxation'. <www.bus.umich.edu $>$ February, 2001, p. 2 accessed on $27^{\text {th }}$ March, 2020.

7. R. James Hines Jr. (n6) p. 7.

8. K. Singh (2005), "Forward from the 'More Taxes, Global Tax Worship', in More Taxes! Promoting Strategies for Global Taxation" (ed) Jorma Penttinen Dark OY, Finland, p. 9.

9. CITA (n3).

10. CITA, Section 105(1).

11. Ibid, Section 13 .

12. M.T. Abdulrazaq, 'New Trends in the Nigeria Law of Company Taxation' (Unpublished paper, University of Ilorin), pp. 11-15. See also De Beers Consolidated Goldmines V. Howe 5TC 198 at 212, Bullock V. Unit Construction Co. 38 T.C. 712, and New Zealand Shipping Co. Ltd V. Thew. 8 T.C. 208 HL.

13. B.B. Kanyip, 'Company Taxation in Nigeria', unpublished LL.M Thesis submitted to Faculty of Law, A.B.U., Zaria, November, 1991, pp. 91-92.

14. B.B. Kanyip Ibid.

15. Ibid.

16. See the cases of Halliburton West African Ltd v FBIR (2006) 7 CLRN 18, and Shell International Maatschappij B.V. v FBIR (2004) 3 NWLR (pt. 895) 46. In both cases, incomes of foreign companies were subjected to the Nigerian corporate tax on the basis that they had a fixed base in Nigeria where profits were derived.

17. B.B. Kanyip (n13) Cap C21.

18. Section 11 CITA, 2004.

19. See Strong \& Co. of Romsery V. Woodfield 5 T.C. 215.

20. Quoted from I.A. Ayua (1996), Nigeria Tax Law, Spectrum Books Ltd., Ibadan p. 124.

21. CITA, Section 24 
22. CITA Ibid. Section 24(i) and (j).

23. Cap. P13 LFN, 2004.

24. CITA (n3).

25. TLRN November, 2009224 at 253.

26. 201623 TLRN 92 at 100.

27. 201518 TLRN 68 at 72.

28. Cap. $21 \mathrm{LFN}, 2004$.

29. 201624 TLRN 40 at 48.

30. S. Ville-Pekka (2005), 'Not Against Windfalls: Fighting Tax Avoidance'. In More Taxes, Promoting Strategies for Global Taxation ATTAC Finland (ed) p. 99 Jorma accessed $<$ www.attac.fi/moretaxes $>27^{\text {th }}$ November, 2019.

31. K. Singh (n8).

32. S. Ville-Pekka (n30).

33. K. Singh (n8).

34. Ibid.

35. 201415 TLRN 119 at 130.

36. S. Ville-Pekka (n30).

37. Supra at p. 131.

38. CITA Section 22.

39. PPTA Section 15(1)

40. CITA.

41. OECD Guidelines for Multinational Enterprises (2008) <www.oecd.org/publishing/corrigenda $>$ p. 25 accessed 18/3/2020.

42. L. Ososemi (July 12, 2004), 'Withholding Tax, Double Taxation Relief and the Pursuit of Foreign Investment' in the Financial Standard.

43. Federal Ministry of Finance, April, 2012.

44. 201415 TLRN 76 at 91.

45. OECD, Model Double Taxation on Income and Capital Report of the OECD Committee on Fiscal Affairs, Paris, 1977.

46. These include the U.K., France, the Netherlands, Belgium, Canada and Pakistan.

47. L. Ososemi (n42).

48. Ibid.

49. 201510 TLRN 84 at 112.

50. See Boucher V. Lawson (1935) cas. Temp. Hard. 85; Holmon V. Johnson (1795) 1 Cowp. 341, Plunche V. Fletcher 1 Doug, ICB 251 (1779).

51. Boucher V. Lawson (Supra).

52. I.O. Agbede (1991), 'Double Taxation and the Problems of Foreign Income'. In Tax Law and Tax Administration in Nigeria, Nigeria Institute of Advanced Legal Studies p. 346, and Section 10(2) Foreign Judgment (Reciprocal Enforcement) Act, 1993.

53. Government of India V. Taylor (1955) A.C. 491.

54. This reasoning is based on the statement of judge Learned hand in Moore V. Mitchel (1929) $30 \mathrm{~F} 2^{\text {nd }} 600$ at 605.

55. A. Yakubu (1999), Limits to the Application of Foreign Laws. Lagos, Mouthouse Press Ltd., $1^{\text {st }}$ edition, p. 2.

56. I.O. Agbede (1989), Themes on Conflict of Laws. $1^{\text {st }}$ ed Lagos Shaneson C.I. Limited, p. 109.

57. Government of India V. Taylor (Supra).

58. A. Yakubu (n55) p. 79.

59. T.A. Ijohor (2003), 'Foreign Revenue Laws and the Nigeria Conflicts of Law'. In Benue State University Law Journal Vol. 2, Makurdi, Peach Global Publication, p. 118.

60. Supra.

61. United Nations Convention Against Transnational Organised Crimes (PALERMO) Convention, 2000. 